\title{
LOUVAIN NATURAL RADIOCARBON MEASUREMENTS IV
}

\author{
E. GILOT, N. ANCION and P. C. CAPRON \\ Department of Nuclear Chemistry, University of Louvain, \\ Louvain, Belgium
}

The following list covers most of the samples measured at the Louvain $\mathrm{C}^{14}$ laboratory since the last list (Louvain III).

The method is essentially the same as the one used for the work described in the previous lists. $\mathrm{A} \mathrm{CH}_{4}$ proportional counter, $0.6 \mathrm{~L}$ volume, operating at $3 \mathrm{~atm}$ pressure, is used. Equipment and counting techniques have been described in Louvain I. Dates are computed on the basis of the Libby half-life, $5570 \mathrm{yr}$, and the zero of the age scale is A.D. 1950. Ages are quoted with $1 \sigma$ experimental error, which includes the counting variations of the sample as well as that of the background and the contemporary standard. As modern standard we now use NBS oxalic-acid standard or wood taken from A.D. 1870 to A.D. 1900 tree rings. No differences between the two standards have been observed.

We wish to acknowledge the help of $F$. Frix in routine operations and chemical preparations. We also thank G. Michotte and D. Rössler for maintenance of electronics. The description and comments are mainly those of persons submitting the samples. Financial support was provided by the "Institut Interuniversitaire des Sciences Nucléaires," Brussels.

\section{SAMPLE DESCRIPTIONS}

\section{Anlier series}

I. GEOLOGIC SAMPLES

Peat from Fange Pouilleuse (49 $43^{\prime} 59^{\prime \prime} \mathrm{N}$ Lat, $5^{\circ} 29^{\prime} 42^{\prime \prime}$ E Long) in forest of Neuchâteau at Villers sur Semois, Prov. of Luxemburg, Belgium, alt $390 \mathrm{~m}$. Coll. 1962 and subm. by W. Mullenders, Univ. of Louvain, Lab. of Palynology.

Lv-61. Anlier I/3

$1820 \pm 100$

Peat from 50.0 to $55.0 \mathrm{~cm}$ below surface, Sub-Atlantic horizon. Comment (W.M.): pollen analysis indicates the 1st beech maximum (Fagus silvatica-FI). Agrees with date of this level at Baraque Michel (Dricot, 1960).

\section{Lv-62. Anlier I/4}

$1930 \pm 130$

Peat from 72.5 to $77.5 \mathrm{~cm}$ below surface. Comment (W.M.): according to pollen analysis, level is the Sub-Boreal-Sub-Atlantic transition with the end of the 5th hazel maximum (Corylus avellana-C IV). Date seems too young; contamination by roots is assumed. 


\section{Lv-63. Anlier I/6}

Peat from 95.0 to $112.5 \mathrm{~cm}$ below surface, Atlantic horizon. Comment (W.M.): pollen analysis shows the 3rd hazel maximum (Corylus avellana-C X) with the classical decrease of Ulmus. Date perfectly agrees with Lv-51 (Louvain III) and with the other datings of this level in the Netherlands, Germany and England (Van Zeist, 1959; Copenhagen IV; Cambridge I).

\section{Lv-64. Anlier I/7}

$3850 \pm 140$

Peat and gyttja with wood remains from 125.0 to $130.0 \mathrm{~cm}$ below surface, Atlantic horizon. Comment: sample is taken from below Lv-63; date is thus more than $1000 \mathrm{yr}$ too young. Contamination by roots is assumed.

\section{Lv-109. Fange aux Mochettes II}

$1620 \pm 100$

Peat from Fange aux Mochettes $\left(50^{\circ} 13^{\prime} \mathrm{N}\right.$ Lat, $5^{\circ} 39^{\prime} \mathrm{E}$ Long) at Samrée, Prov. of Luxemburg, Belgium, alt $600 \mathrm{~m}$. Sample taken at depth of 90 to $100 \mathrm{~cm}$ below surface. Coll. 1962 and subm. by W. Mullenders. Comment (W.M.): Sub-Atlantic horizon. Sample from between the lst and 2nd beech maximum (Fagus silvatica-F I and F II). Date agrees with expectations.

\section{Rouge Ponceau series}

Peat or gyttja from Rouge Ponceau $\left(50^{\circ} 04^{\prime} \mathrm{N}\right.$ Lat, $5^{\circ} 25^{\prime}$ E Long) at Tenneville, Prov. of Luxemburg, Belgium, alt $545 \mathrm{~m}$. Coll. 1961 and 1962 and subm. by W. Mullenders.

General Comment for the gyttjas: samples are very poor in organic matter and cannot be burned. They are not pretreated. Humic matter is dissolved in $\mathrm{NaOH}$ and precipitated from solution by HCl. After washing, the precipitate is used for age determination. Age is thus a minimum age, because possible recent humic contamination is not removed.

\section{Lv-150. Rouge Ponceau III $/ \mathbf{l}$}

$\mathbf{5 5 0} \pm \mathbf{1 3 0}$

Peat from 22.5 to $25.0 \mathrm{~cm}$ below surface, Sub-Atlantic horizon. Comment (W.M.): this level is the 3rd beech maximum (Fagus silvatica -F III). Date appears satisfactory.

\section{Lv-151. Rouge Ponceau III/2}

$1450 \pm 110$

Peat from 42.5 to $50 \mathrm{~cm}$, Sub-Atlantic horizon. Comment (W.M.): sample covers the 2nd beech maximum (Fagus silvatica-F II). Palynologically estimated age ca. $1400 \mathrm{yr}$ ago. 


\section{Lv-152. Rouge Ponceau III $/ 3$}

Peat from 52.5 to $60.0 \mathrm{~cm}$, Sub-Atlantic horizon. Comment (W.M.): this level contains the 1st beech maximum (Fagus silvatica-F I). Date seems to be reasonable although too old in comparison with Lv-61 (this list).

\section{Lv-153. Rouge Ponceau III $/ 4$}

Peat from 67.5 to $75.0 \mathrm{~cm}$, Sub-Boreal horizon. Comment (W.M.): sample confirms age of 5th hazel maximum (Corylus avellana-C IV), and corresponds well with palynological results. The same level in the Netherlands was dated at $3090 \mathrm{yr}$ ago (Van Zeist, 1955).

\section{Lv-154. Rouge Ponceau III /5}

$3380 \pm 180$

Peat from 90.0 to $100.0 \mathrm{~cm}$ below surface. Comment (W.M.): at this level is situated the Atlantic-Sub-Boreal transition. Pollen analysis shows hazel increase, probably the 4th maximum (Corylus avellana-C III). Date seems 500 yr too young in comparison with C III dates in Germany and the Netherlands. Further investigations are necessary.

\section{Lv-144. Rouge Ponceau I/2}

$6160 \pm 260$

Peat from 127.5 to $140.0 \mathrm{~cm}$ below surface. Comment (W.M.): at this level comes the Boreal-Atlantic transition, palynologically estimated age ca. 7500 yr ago. Date thus seems much too young. But the pollen diagram shows major variations, so that the presence of unconformities is not impossible.

\section{Lv-145. Rouge Ponceau $I / 3$}

Clayey peat from 165.0 to $187.5 \mathrm{~cm}$ below surface. Comment (W.M.): sample covers the Pre-Boreal-Boreal transition, palynologically estimated age ca. 8500 yr ago. Same level in the Netherlands is dated at $8625 \pm 180$ (Van Zeist, 1955).

\section{Lv-146. Rouge Ponceau $I / 4$}

$8130 \pm 210$

6180 B.C.

Gyttja from 190 to $200 \mathrm{~cm}$ below surface, Pre-Boreal horizon. Comment: according to estimated age for Pre-Boreal-Boreal transition, date is a little too young. But as humic contamination was not removed, date is minimum.

\section{Lv-147. Rouge Ponceau I/5}

Gyttja from 220 to $225 \mathrm{~cm}$, Pre-Boreal horizon. Comment: sample is taken from below Lv-146; date is thus much too young. Humic contamination is assumed. 


\section{Lv-148. Rouge Ponceau I/6}

Gyttja from 230 to $235 \mathrm{~cm}$, Pre-Boreal horizon. Comment (W.M.): pollen analysis gives no precision. Date seems to be reasonable.

\section{Lv-149. Rouge Ponceau I/ 7}

$9090 \pm 230$

Gyttja from 240 to $250 \mathrm{~cm}$, Pre-Boreal horizon. Comment (W.M.): pollen diagram gives no precision. Date appears satisfactory.

\section{Tourbière du Grand Passage series}

Peat from Tourbière du Grand Passage $\left(50^{\circ} 17^{\prime} 31^{\prime \prime} \mathrm{N}\right.$ Lat, $5^{\circ} 45^{\prime}$ 12" E Long), near Les Tailles, Prov. of Luxemburg, Belgium, alt $605 \mathrm{~m}$. Coll. 1963 and subm. by W. Mullenders. First part of this series is published in Louvain II (Lv-57 to Lv-60).

\section{Lv-155. Grand Passage $\mathrm{V} / \mathbf{1}$}

Peat from 40 to $50 \mathrm{~cm}$ below surface, Sub-Atlantic horizon. Comment (W.M.): pollen analysis indicates a level between the $3 \mathrm{rd}$ and 4 th beech maximum (Fagus silvatica-F III and F IV). Date agrees with Lv57 and with pollen chronology.

\section{Lv-157. Grand Passage V/3}

$$
\begin{array}{r}
1310 \pm 100 \\
\text { A.D. } 640
\end{array}
$$

Peat from 80 to $90 \mathrm{~cm}$ below surface, Sub-Atlantic horizon. Comment: according to pollen analysis, sample is taken from below the 3rd beech maximum (Fagus silvatica-F III). Date appears satisfactory, although a little too old in comparison with Lv-159. The difference is probably due to statistical errors.

\section{Lv-159. Grand Passage V/6}

$$
1200 \pm 130
$$

Peat from 120 to $135 \mathrm{~cm}$, Sub-Atlantic horizon. Comment: sample from between the 2nd and 3rd beech maximum (Fagus silvatica-F II and F III). A similar horizon is dated at $1100 \pm 90$ (Lv-58).

\section{Lv-161. Grand Passage V/8}

$$
1740 \pm 110
$$

Peat from 145 to $155 \mathrm{~cm}$, Sub-Atlantic horizon. Comment (W.M.): sample from between the 1st and 2nd beech maximum (Fagus silvaticaF I and FII). Date agrees with pollen analysis.

\section{Terneuzen series}

Wood from fossil pine stand at Terneuzen $\left(51^{\circ} 19^{\prime} \mathrm{N}\right.$ Lat, $3^{\circ} 48^{\prime} \mathrm{E}$ Long), Zealand Flanders, the Netherlands, at sealevel. The trunks were covered by Sub-Boreal peat, $150 \mathrm{~cm}$ thick, under Sub-Atlantic clay, 100 $\mathrm{cm}$ thick. Coll. 1962 and subm. by A. Munaut, Univ. of Louvain, Lab. 
of Palynology and Dendrochronology. Comment: the following samples represent the last part of the program to test the dendrochronologic method in the Terneuzen site (see Louvain II and III). Results are analyzed in a thesis by A. Munaut.

Lv-130. Terneuzen pine T 36

$4430 \pm 140$

Wood from pine stub in situ (Pinus silvestris, id. by E. Frison) from peat $180 \mathrm{~cm}$ below ground surface. Sample taken from the last growth rings. The first growth rings of the same pine were dated at 2750 B.c. \pm 120 (Lv-129, Louvain III).

\section{Lv-131. Terneuzen pine $\mathbf{T} 7$}

$4510 \pm 150$

Wood from pine stub in situ (Pinus silvestris, id. by E. Frison) from peat $180 \mathrm{~cm}$ below ground surface. Sample taken from the first growth rings. Last growth rings of same pine were dated at 2430 B.c. \pm 120 (Lv-115, Louvain II).

\section{Lv-133. Terneuzen pine $\mathbf{T} 637$}

$4430 \pm 130$

2480 B.C.

Wood from pine stub in situ (Pinus silvestris, id. by E. Frison) from peat $180 \mathrm{~cm}$ below ground surface. Sample taken from the first growth rings. Last growth rings of same pine were dated at 2170 B.c. \pm 120 (Lv127, Louvain III).

\section{Lv-134. Terneuzen pine T 246}

$5010 \pm 130$ 3060 B.c.

Wood from pine stub in situ (Pinus silvestris, id. by E. Frison) from peat $180 \mathrm{~cm}$ below ground surface. Sample taken from the first growth rings. Last growth rings of same pine were dated at 2620 B.c. \pm 130 (Lv114, Louvain II).

\section{Lv-230. Burcht}

$11,550 \pm 330$

9600 B.c.

Vegetable peat from Burcht (51 $11^{\circ} 12^{\prime} \mathrm{N}$ Lat, $4^{\circ} 30^{\prime} \mathrm{E}$ Long), prov. of Eastern Flanders, Belgium, alt $6 \mathrm{~m}$ below sealevel. Sample is taken at $15 \mathrm{~m}$ depth from a peat layer carried in a Quaternary gravel underlying sand and clay layer 2 to $3 \mathrm{~m}$ thick. Above the clay level, a Holocene peat layer. In gravel and sand above the sampled peat layer was found a rich Würmian fauna, age of which is estimated ca. 60,000 yr. Coll. 1965 by R. Paepe; subm. by A. Delmer and R. Paepe, Service Geol. de Belgique. Comment (A.D.R.P.): age determination made to fix the shore line of old Scheldt estuary. Date shows that the site was altered. Sampled peat and bones were carried there during a period posterior to the age of this peat, but before the formation of the Holocene peat layer, thus probably during the Dryas period. 


\section{Lv-216. Mesvin 2}

$5340 \pm 150$

3390 в.C.

Charcoal from Sans Pareil mine $\left(50^{\circ} 24^{\prime} 53^{\prime \prime} \mathrm{N}\right.$ Lat, $3^{\circ} 57^{\prime} 24^{\prime \prime} \mathrm{E}$ Long) at Mesvin, Prov. of Hainaut, Belgium. Sample found under a big kidney-shaped silex still partly imbedded in chalk geologic stratum in North gallery of shaft I at $3.30 \mathrm{~m}$ depth. Gallery was not filled up, but closed by dirt in the shaft. Coll. 1957 by Joris and Lefrancq; subm. by P. H. Moisin, Société de Recherche Préhistorique en Hainaut. Comment (P.H.M.): sample corresponds to age of actual stone extraction. Date agrees perfectly with Lv-65 (Louvain II) dated 3270 B.c. \pm 170 , and corresponding to the mine filling-up.

\section{Lv-208. Montbec}

$3260 \pm 160$

\section{B.c.}

Wood from hunting or fishing spear found at $1.50 \mathrm{~m}$ depth in the Neuchatel lake in prehistoric site of Montbec $\left(46^{\circ} 56^{\prime} \mathrm{N}\right.$ Lat, $6^{\circ} 58^{\prime} \mathrm{E}$ Long) near Chabrey, Canton of Vaud, Switzerland. Coll. 1941 and subm. by E. Borel, Prehist. Commission Neuchatel Canton. Comment (E.B.): weapon should be contemporary with the last occupation of the site.

\section{Salies de Béarn series}

Charcoal from Salies de Béarn (43 $28^{\prime} \times$ Lat, $0^{\circ} 55^{\prime} \mathrm{W}$ Long) in Béarn, Dept. of the Lower Pyrenees, France. Charcoal together with potsherds was found at $60 \mathrm{~cm}$ depth in a muddy clay layer covered by broken stones and brown clay. Coll. 1965 by Arambourou and subm. by Thibault, Univ. of Bordeaux, Lab of Prehist. Comment (T.): potsherds correlated with a salt mine in the next Triassic level; estimated Iron age, perhaps Bronze age.

\section{Lv-246. Salies de Béarn A}

$3210 \pm 170$

\section{Lv-247. Salies de Béarn E}

Comment: because of experimental conditions of the measurements, difference is not significant.

\section{Alba Fucens series}

Charcoal from embankment behind the first enceinte at Alba Fucens $\left(42^{\circ} 05^{\prime} \mathrm{N}\right.$ Lat, $13^{\circ} 25^{\prime} \mathrm{E}$ Long), Prov. of Aquila, Italy. Samples from Excavation 121, Level 2. Coll. 1957 and subm. by J. Mertens, Univ. of Louvain, Archaeol. Inst.

\section{Lv-28. Alba Fucens 121-2/a}

$$
\begin{aligned}
& 2310 \pm 90 \\
& 360 \text { в.C. } \\
& 2360 \pm 90 \\
& 410 \text { B.C. }
\end{aligned}
$$$$
\text { Lv-179. Alba Fucens 121-2/b }
$$

General Comment (J.M.): at a few meters from the samples was found a coin not older than the beginning of the 3rd century B.c., but it is pos- 
sible that the dirt comes from an older burned horizon and was brought there for the embankment.

\section{Hamont series}

Charcoal from prehistoric burial mounds at Hamont $\left(\begin{array}{lll}51^{\circ} & 16^{\prime} \mathrm{N}\end{array}\right.$ Lat, $5^{\circ} 30^{\prime} 30^{\prime \prime} \mathrm{E}$ Long), Prov. of Limburg, Belgium. Coll. 1963 by W. Thyssen, Service des Fouilles, Brussels; subm. by J. Mertens.

\section{Lv-191. Hamont T III AB}

$2520 \pm 120$

570 B.c.

Sample from a Neolithic or Bronze age burial mound, at $95 \mathrm{~cm}$ below the top. Comment (J.M.): $\mathrm{C}^{14}$ date agrees with archaeologic date.

\section{Lv-192. Hamont T III AE}

$2880 \pm 150$

Sample from prehistoric burial mound, at $80 \mathrm{~cm}$ below the top. Comment (J.M.): $\mathrm{C}^{14}$ date agrees with archaeologic date.

\section{Lv-228. Vaux sous Chèvremont}

$\mathbf{5 4 0} \pm \mathbf{8 0}$

Charcoal from burned horizon of feudal castle of Chèvremont $\left(50^{\circ}\right.$ $36^{\prime} \mathrm{N}$ Lat, $5^{\circ} 37^{\prime} \mathrm{E}$ Long) at Vaux sous Chèvremont, Prov. of Liège, Belgium. Sample is taken at $1.15 \mathrm{~m}$ depth. Coll. 1965 and subm. by J. Mertens. Comment (J.M.): castle was destroyed in the 10th century; $\mathrm{C}^{14}$ date is still unexplained.

\section{Lv-40. Gistel III}

$4330 \pm 120$

2380 B.c.

Charcoal from Gistel ( $51^{\circ} 09^{\prime} \mathrm{N}$ Lat, $2^{\circ} 57^{\prime}$ E Long), Prov. of Western Flanders, Belgium. Sample taken at $1.50 \mathrm{~m}$ depth in the original sand layer below a Middle Age artificial eminence. Coll. 1958 and subm. by J. Mertens. Coment: pollen analysis, by W. Mullenders, shows at this level the Sub-Boreal-Sub-Atlantic transition, with perhaps the end of Atlantic horizon. Age of that transition is estimated ca. $4000 \mathrm{yr}$ ago.

\section{Zoutenaaie series}

Samples from Zoutenaaie ( $51^{\circ} 03^{\prime} \mathrm{N}$ Lat, $2^{\circ} 45^{\prime} \mathrm{E}$ Long), Prov. of Western Flanders, Belgium, alt $4 \mathrm{~m}$. Coll. 1960 and subm. by J Mertens. Age determination in order to see the succession of the marine transgressions.

\section{Lv-85. Zoutenaaie 60.Zo.8}

$2060 \pm 130$

110 B.C.

Wood from Excavation I, Profile AB. Comment (J.M.): archaeologic estimate 1st century B.c.

\section{Lv-86. Zoutenaaie 60.Zo.12}

$2490 \pm 130$

Charcoal from Excavation II, agrees with archaeologic estimation. 
Lv-90. Zoutenaaie 60.Zo.38

Peat from Excavation VII, Profile AB.

380 B.c.

Lv-91. Zoutenaaie 60.Zo.39

$3000 \pm 110$ Lv-90.

Pine stub in situ (Pinus silvestris, id. by J. Heim) at same level as

\section{Lv-193. Male}

A.D. 1350

$600 \pm 110$

Wood from beam used in basement of feudal castle of Male $\left(51^{\circ} 11^{\prime}\right.$ $30^{\prime \prime} \mathrm{N}$ Lat, $3^{\circ} 16^{\prime} \mathrm{E}$ Long) at Sint-Kruis, Prov. of Western Flanders, Belgium. Sample taken at $2.20 \mathrm{~m}$ depth. Coll. 1962 by L. Devliegher; subm. by Mertens. Comment (J.M.): $\mathrm{C}^{14}$ date agrees with archaeologic date.

Date lists:

\section{REFERENCES}

Cambridge I Godwin and Willis, 1959

Copenhagen IV Tauber, 1960

Louvain I Dossin, Deumer and Capron, 1962

Louvain II Deumer, Gilot and Capron, 1964

Louvain III Gilot, Ancion and Capron, 1965

Crèvecoeur, E. H., Vander Stricht, A., and Capron, P. C., 1959, Precision of the dating method. Standardization of the calculation of the errors and the maximum age in the $\mathrm{C}^{14}$ method: Acad. Royale Belgique Bull. Cl. Sci., v. 45, p. 876-890.

de Visscher, F., Mertens, J., 1958, Alba Fucens: Rendi Conti Accad. Lincei, v. 8, fasc. 13, p. 97-106.

Dricot, E. M., 1960, Recherches palynologiques sur le plateau des Hautes Fagnes: Soc. Royale de Bot. Belgique Bull., v. 92, p. 157-196.

Erdtman, G., 1927, Vestige de l'histoire quaternaire récente des forêts belges: Acad. Royale Belgique Bull. Cl. Sci., v. 13, p. 656-660.

Godwin, H., 1962, Half-life of radiocarbon: Nature, v. 195, no. 4845, p. 984

Heim, J., 1960, Recherches sur les relations entre la végétation actuelle et le spectre pollinique récent dans les Ardennes belges: thesis, Louvain Agron. Inst.

Janssen, C. R., 1960, On the Late-Glacial and Post-Glacial Vegetation of South Limburg: Amsterdam, 112 p.

Lefrancq, M. G., Moisin, P. H., 1965, Le néolithique ancien en Belgique. Datage au C 14 (Lv-65 et -216) de la minière de Mesvin "Sans Pareil", Hainaut: Soc. Sci. Arts et Lettres Hainaut Mem. and Publ., v. 79, fasc. 2, p. 405-429, 4 pl.

Mullenders, W., 1964, La position phytogéographique des hauts plateaux belges: Vegetatio, v. 5-6, p. 112-119.

Mullenders, W., Knop, C., 1962, La Tourbière du Grand Passage: Soc. Royale de Bot. Belgique Bull., v. 94, p. 163-175.

Munaut, A., 1963, La forêt fossile de Terneuzen: Soc. Royale de Bot. Belgique Bull., v. 96 , fasc. 2 , p. 456 .

1965, Recherches paléoécologiques en Basse et Moyenne Belgique (et dans les régions limitrophes): thesis, Louvain Agron. Inst.

Roosens, H., Beex, G., 1965, Bronstijdgrafheuvels op de haarterheide te Hamont: Archaeologica Belgica, v. 81, 30 p., 8 pl.

Van den Berghen, C., 1951, Landes tourbeuses et Tourbières bombées à Sphaignes de Belgique: Soc. Royale de Bot. Belgique Bull., v. 84, p. 157-226.

Vanhoorne, R., 1956, Etude palynologique de la Fange aux Mochettes à Samrée (Belgique): Inst. Royal Sci. Nat. Belgique Bull., v. 32, p. 1-7.

Van Zeist, W., 1955, Some radiocarbon dates from the raised bogs near Emmen (Netherlands): Palaeohistoria, v. 4, p. 113-118.

1959, Studies on the post-boreal vegetational history of southeastern

Drenthe (Netherlands): Acta Botanica Neerlandica, v. 8, p. 156-184. 